\title{
Cucurbita pepo and Cucurbitacin in the Management of Anti-proliferation by JAK/STAT Pathway
}

\author{
Souvik Mukherjee, Dilipkumar Pal* \\ Department of Pharmaceutical Sciences, Guru Ghasidas Vishwavidyalaya (A Central University), Bilaspur, Chhattisgarh, INDIA.
}

\begin{abstract}
Pumpkin (Cucurbita pepo) is capaciously recycled similar to food and in folk medicine throughout the world. It accords to genus Cucurbita $\left(C_{C_{T}}\right)$ under family Cucurbitaceae. There are a plenty of important medicinal phyto-constituents belonging to cucurbitoside like triterpenoids, $C^{A R}$ and $C_{C T}$ glycosides. A survey of the literature demonstrates that $C$. pepo, has the capacity to improve prostatic hyperplasia, urinary dysfunction and cytotoxic properties. Many pharmacological revisions have established its role in hepatoprotection, inhibition of $P_{r}^{\text {st }}$ gland cancer $\left(C_{N C R}\right)$, anti $\left(A_{t}^{n}\right)$ oxidant effects, inhibition of $L_{u}{ }^{G}$, $B_{R}{ }^{\text {st }}$ and triple-negative $B_{R}^{\text {st }} C_{N C R}$ by blocking JAK/STAT signaling $\left(S_{\text {gls }}\right)$ pathway $\left(P_{t w}\right)$. It has also $A^{n}{ }_{t}$ microbial, $A^{n}{ }_{t}$-inflammatory, $A_{t}^{n}$-diabetic and $A^{n}{ }_{t}$ ulcer activities by supporting its traditional claims. Establishment of $C$. pepo and cucurbitacin $\left(C_{C B T}\right)$ in the management of $A^{n}{ }_{t}$-proliferation by JAK/STAT $P_{t w}$. Data towards writing this review are generated through exploration of different websites like MEDLINE (PubMed), Google Scholar, Science Direct, Scopus, Cochrane, SID and Magiran databases. We have selected 2016 2018 duration for the same purpose. We have found 88 papers related to this topic. $\mathrm{C}_{\mathrm{CBT}}$ is found to arrest unlimited cell $\left(C_{E L}\right)$ division and respective apoptosis $\left(A_{p p t}\right)$ in vitro and in vivo $\mathrm{C}_{\mathrm{NCR}}$ models. A plenty of molecular design targeting $\mathrm{C}_{\mathrm{CBT}}$ have been invented, such as fibrous-actin, $\mathrm{S}_{\mathrm{gls}}$ transducer and activator of transcription (STAT), cyclooxygenase-2, etc. This review is minded at $C_{C B T}$ from $C$. pepo which dwindle the proliferation of human $\mathrm{C}_{\mathrm{NCR}} \mathrm{C}_{\mathrm{EL}}$ through the JAK/STAT $\mathrm{P}_{\mathrm{tw}}$.
\end{abstract}

Key words: Anticancer activity, Cucurbita pepo, Cucurbitaceae family, JAK/STAT pathway, Cucurbitacin, Cyclooxygenase-2.

\section{INTRODUCTION}

$\mathrm{C}_{\mathrm{NCR}}$ lies its uniqueness to the maximum normally identified diseases $\left(\mathrm{D}_{\text {SEAS }}\right)$ and is associated with ill health and death set up causing a health problem globally. Even though unlimited determinations have been found ready to find out a remedy, $\mathrm{C}_{\mathrm{NCR}}$ remnants a very projecting cause of death in humans. Carcinogenesis $\left(\mathrm{C}_{\mathrm{CNG}}\right)$ is a different step and different factorial process including the incidence of vibrant and disconnected molecular and $\mathrm{C}_{\mathrm{EL}}$ modifications. There are different but thoroughly associated stages of origination, elevation and development are found in $\mathrm{C}_{\mathrm{NCR}}{ }^{1}$ Present-day $\mathrm{C}_{\mathrm{NCR}}$ treatments, chemotherapy, targeted agents, radiation, surgery and immunosuppression have restrictions subsequent from the expansion of resistance to the treatment. The identification of defensive molecules starved of side effects ruins a crucial independent in the fight against $\mathrm{C}_{\mathrm{NCR}}$. The additional choices goal next to the initial finding of $\mathrm{C}_{\mathrm{NCR}}$ in the preliminary stage can assist with its appropriate supervision. In the meantime, plant $\left(\mathrm{P}_{\mathrm{L} t}\right)$-derived products have taken a major role to inhibit numerous chronic $\mathrm{D}_{\text {SEAS }}$, as well as $\mathrm{C}_{\mathrm{NCR}}$. The use of $\mathrm{P}_{\mathrm{Lt}}$ substances to inhibit or defer the growth of $\mathrm{C}_{\mathrm{CNG}}$ has been called for chemoprevention and there is a rapid increasing attention towards the usage of natural compounds as probable chemo-protective and therapeutic
Submission Date: 10-01-2020; Revision Date: 17-07-2020; Accepted Date: 20-01-2021

DOI: 10.5530/ijper.55.1.3 Correspondence: Dr. Dilipkumar Pal Associate Professor, Department of

Pharmaceutical Sciences, Guru Ghasidas,

Vishwavidyalaya, Bilaspur-495 009, Chhattisgarh, INDIA.

Phone: +91 077522-258878 E-mail: drdilip71@gmail.com

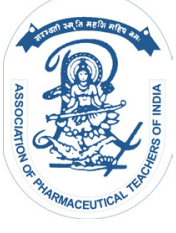

www.ijper.org 
agents. ${ }^{2}$ Pumpkin $\left(\mathrm{P}_{\mathrm{MPN}}\right)$ seed $\left(\mathrm{S}_{\mathrm{Ed}}\right)$ has several health benefits. $\mathrm{P}_{\text {MPN }}$ is refined all over the biosphere for usage as root vegetables as well as medicine. ${ }^{3} \mathrm{It}$ is also recycled by tradition as medicine in many nation-states such as China, Yugoslavia, Argentina, India, Mexico, Brazil and America. Its extensively detained medicinal $\left(\mathrm{M}_{\text {edd }}\right)$ usages have concentrated investigation with modern implements and recognized with good $\mathrm{A}^{\mathrm{n}}{ }_{\mathrm{t}}$-diabetic, $\mathrm{A}^{\mathrm{n}}{ }_{\mathrm{t}}$ -hypertension, $A^{n}{ }_{t}-\operatorname{tumor}\left(t^{m}{ }_{R}\right)$, immunomodulation, $\mathrm{A}^{\mathrm{n}}{ }_{\mathrm{t}}$ bacterial, $\mathrm{A}^{\mathrm{n}}{ }_{\mathrm{t}}$-hypercholesterolemia, intestinal $\mathrm{A}^{\mathrm{n}}{ }_{\mathrm{t}}$ -parasitic, $\mathrm{A}^{\mathrm{n}}{ }_{\mathrm{t}}$-inflammatory and analgesic properties. ${ }^{4}$

\section{Cucurbita pepo}

$\mathrm{P}_{\text {MPN }}$ (Cucurbita pepo) is one of the eldest identified nurtured classes of shrub. It accords to the genus $\mathrm{C}_{\mathrm{CT}}$ and family Cucurbitaceae or $\mathrm{C}_{\mathrm{CT}}$ and contain crops like cucumbers. Ethno-pharmacological studies display that C. pepo is recycled in various countries for treating many $\mathrm{D}_{\text {SEAS }}$ like inflammation, viral infections, pain, urinary disorders, ulcer, diabetes and oxidation. ${ }^{5}$ Mainly Ayurveda system has used to assess segment of the $\mathrm{P}_{\mathrm{Lt}}$ as well as corpuscles of the fruits $\left(\begin{array}{c}\mathrm{Fr} \\ { }^{u}\end{array}\right)$ and $\mathrm{S}_{\mathrm{Ed}}$. The $\mathrm{S}_{\mathrm{Ed}}$ are recycled to treat the problems of urinary system, hypertension, kidney stones, prostate $\left(\mathrm{P}_{\mathrm{r}}^{\mathrm{st}}\right) \quad \mathrm{D}_{\text {SEAS }}$, erysipelas skin $\left(\begin{array}{l}\mathrm{sk} \\ \mathrm{N}\end{array}\right)$ infection and carcinomas $\left(\mathrm{C}_{\text {Arom }}\right)$. Exact cultivars of winter squash resulting from other species such as C. argyrosperma and C. moschata, are also at times called " $\mathrm{P}_{\mathrm{MPN}}{ }^{6}$

\section{Taxonomical Classification of C. pepo}

Taxonomic classification. ${ }^{7}$

Kingdom: Plantae

Subkingdom: Tracheobionta

Super division: Spermatophyta

Division: Magnoliopsida

Subclass: Dileniidae

Order: Violales

Family: Cucurbitaceae

Genus: $\mathrm{C}_{\mathrm{CT}} \mathrm{L}$

Species: $\mathrm{C}_{\mathrm{CT}}$ pepo $\mathrm{L}$

\section{Vernacular Names}

Hindi: Safed Kaddu, Kumrha Marathi: Kohala, Bhopli Telugu: budadegummadi, Bengali: Safed Kaddu, Sanskrit: karkaru, kurkaru and kurlaru, kushmanda English: squash. ${ }^{8,9}$

\section{Habitat}

$\mathrm{P}_{\mathrm{MPN}}$ are full-fledged throughout the biosphere for a diversity of explanations extending from agronomic ulterior motive. Only Antarctica is not capable to harvest $\mathrm{P}_{\mathrm{MPN}}$. The major international manufacturers of $\mathrm{P}_{\mathrm{MPN}}$ consist of the United States, Canada, Mexico, India and China. ${ }^{10}$

\section{Plant Characteristics}

$\mathrm{P}_{\text {MPN }}$ is yearly parsley with heavy mounting stems. The root is thriving established and towards $40 \mathrm{~cm}$ unfathomable with $5 \mathrm{~m}$ extended. The stems are a branch off, enclosed in spongy white up to $10 \mathrm{~m}$ long and frequently yield extrinsic roots at nodes. The petioles are 5-20 cm long. The tinny leaves are alternative, modest, palmate, veined, round to reniform, essentially cordate, apically obtuse, unsubdivided to trivial 5-7 lobed, $7-30 \mathrm{~cm}$ across, wide-ranging than long, stark to soft blooming and finely margin with toothlike projection, 3-5 rounded or obtuse, apiculate lobules, the central one bigger than lateral ones. ${ }^{11,12}$ Unisexual flowers of $\mathrm{P}_{\mathrm{MPN}}$ are aromatic. The calyx is enclosed in white pubescence and bears 5 free sepals, $0.5-2 \mathrm{~cm}$ long. The corolla is yellow to orange color, tubular at least $5 \mathrm{~cm}$ long and broad. Staminate flowers are about $10-23 \mathrm{~cm}$ long. Pistillate flowers are grown on shorter pedicles, only up to $5.5 \mathrm{~cm}$ long and have an inferior 1- ocular ovoid ovary with a short thick style with 3-5 bilobed stigmas. ${ }_{\mathrm{Fr}}^{\text {ut }}$ are are highly inconstant in shape, color and size. ${ }^{13}$ The shape is elongated, cylindrical, oval, flattened, globular, heart-shaped and tapering to a curved neck on one or both ends. The length is from 5.8 to $71.6 \mathrm{~cm}$ and width from 11.2 to $48.6 \mathrm{~cm}$. The ${ }_{\mathrm{N}}^{\mathrm{Sk}}$ can be smooth, wrinkled. The flesh, variable in color and thickness can be white, yellow, or orange and 1 to $6.4 \mathrm{~cm}^{\text {thick }}{ }^{14}$ [Figure 1].

\section{$\mathrm{S}_{\mathrm{Ed}}$ Characteristics}

$\mathrm{P}_{\text {MPN }} \mathrm{S}_{E d}$ is also recognized as pepita. The $\mathrm{S}_{\mathrm{Ed}}$ are characteristically flat, unequally oval, light green in color and typically enclosed by a white husk [Figure 2$] \cdot{ }^{15} \mathrm{P}_{\mathrm{MPN}}$ $\mathrm{S}_{\mathrm{Ed}}$ produce $34-54 \%$ oil. The size and weight of the $\mathrm{S}_{\mathrm{Ed}}$ rise as the ${ }_{\mathrm{Fr}}^{\text {ut }}$ size rises, lining up between 1.6 to $2.9 \mathrm{~cm}$ long, 0.7 to $1.6 \mathrm{~cm}$ wide and 0.28 to $0.69 \mathrm{~cm}$ thick. The $\mathrm{S}_{\mathrm{Ed}}$ seem doable for 6-8 years but abide by no endosperm and the embryo embody leaf-like cotyledons and a short radicle. ${ }^{16} \mathrm{P}_{\mathrm{MPN}} \mathrm{S}_{\mathrm{Ed}}$ oil is popular as succulent oil and also used as a nutritious food. $\mathrm{P}_{\mathrm{MPN}} \mathrm{S}_{\mathrm{Ed}}$ and its oil are prosperous in phytosterols, polyunsaturated fatty acids $\left(\mathrm{F}_{\mathrm{TA}}\right), \mathrm{A}_{\mathrm{t}}^{\mathrm{n}}$-oxidant vitamins, carotenoids $\left(\mathrm{C}_{\mathrm{T}}^{\mathrm{AR}}\right)$, Tocopherols and its versatile facets such as protein, magnesium, copper and zinc. Due to the presence of these constituents, $\mathrm{P}_{\mathrm{MPN}}$ are recognized as a good reservoir for providing many health remunerations. ${ }^{17}$

\section{Chemical composition of C. pepo}

These are categorized through a low contented fat $(2.3 \%)$, mono-di-poly saccharides (66\%), proteinoids substances $(3 \%)$ and high $\mathrm{C}_{\mathrm{T}}^{\mathrm{AR}}$ contented with 
magnitudes of 171.9 to 461.9 microgram. ${ }^{18}$ The mineral investigation specified that $\mathrm{P}_{\mathrm{MPN}}$ pulp is enclosed with great levels of elements which shown in Table 1. ${ }^{19-21}$ The structure of $\mathrm{P}_{\text {MPN }} \mathrm{S}_{\mathrm{Ed}}$ is reasonably varying. The content of amino acids $\left(\mathrm{A}_{\mathrm{d}}^{\mathrm{C}}\right), \mathrm{F}_{\mathrm{TA}}$ and minerals may differ significantly, depending on changed conditions. Such changes may be affected by differences in cultivar or origin. $\mathrm{P}_{\mathrm{MPN}} \mathrm{S}_{\mathrm{Ed}}$ contain $50 \%$ fatty oil which is dark green and rich in free $\mathrm{F}_{\mathrm{TA}}$. The arrangement of $\mathrm{F}_{\mathrm{TA}}$ differs on numerous factors $\left(\mathrm{F}^{\mathrm{CT}}\right)$ like the variety of places where the $\mathrm{P}_{\mathrm{Lt}}$ are developed, weather, growth $\mathrm{F}^{\mathrm{CT}}$ and favoring ripeness. ${ }^{22}$ The instabilities in the oil constituents is very high, subsequent from a wide $G^{\mathrm{n}}$ evariation, farming atmosphere, storage time and storage conditions. The glyceride part content variates from $73.1 \%$ to $80.7 \%$ unsaturated $\mathrm{F}_{\mathrm{TA}}$, mainly oleic acids $\left(\mathrm{OA}_{\mathrm{d})}^{\mathrm{C}}\right.$ and linoleic $(\mathrm{L}$ $\left.A_{d}^{C}\right)$. Again, the same fraction contains $19 \%$ saturated $\mathrm{F}_{\mathrm{TA}}$ consisting of mainly palmitic $\left(\mathrm{P} \mathrm{A}_{\mathrm{d}}^{\mathrm{C}}\right)$ and stearic acids $\left(\mathrm{S}_{\mathrm{d}}^{\mathrm{C}}{ }_{\mathrm{d}}\right)(6 \%)$. Several studies have reported similar types of data regarding proportions of total $\mathrm{F}_{\mathrm{TA}}$ or free $\mathrm{F}_{\mathrm{TA}}$ in the cake fraction of $\mathrm{P}_{\mathrm{MPN}} \mathrm{S}_{\mathrm{Ed}}: 29.9 \% \mathrm{~L} \mathrm{~A}_{\mathrm{d}}^{\mathrm{C}}$ and $\mathrm{OA}_{\mathrm{d}}^{\mathrm{C}} 50.4 \%$ [Table 2].

$\mathrm{P}_{\text {MPN }} \mathrm{S}_{\mathrm{Ed}}$ are enclosed comparatively huge quantities of $\mathrm{K}$ $(5,790 \mu \mathrm{g} / \mathrm{g}$ dry weight) and chromium (approximately $3 \mu \mathrm{g} / \mathrm{g}$ dry weight), $\mathrm{Na}$ content of same $\mathrm{S}_{\mathrm{Ed}}$ is low (6.9 $\mu \mathrm{g} / \mathrm{g}$ dry weight). Other minerals present in $\mathrm{P}_{\mathrm{MPN}} \mathrm{S}_{\mathrm{Ed}}$ are: $\mathrm{P}(15,700) ; \mathrm{Ca}$ (346); iron (106); Mn (49.3); Al (9.21); Ba (1.16); Co (0.29); strontium (1.83); Ni (0.53); As (0.45) (in $\mu \mathrm{g} / \mathrm{g}$ dry weight). Notable is the low amounts of calcium in the $\mathrm{S}_{\mathrm{Ed}}$. One hundred-gram roasted $\mathrm{P}_{\mathrm{MPN}}$ $\mathrm{S}_{\mathrm{Ed}}$ contain $25.94 \mathrm{mg} \mathrm{Ca}$, $955.81 \mathrm{mg} \mathrm{P}$ and $8.06 \mathrm{mg}$ of $\mathrm{Fe}^{23-25}$

Numerous constituents such as $\mathrm{C}^{\mathrm{AR}}{ }_{\mathrm{T}}$, as lutein $\left(\mathrm{L}_{\mathrm{n}}^{\mathrm{t}}\right), \mathrm{L}_{\mathrm{n}}^{\mathrm{t}}$ epoxide, 15- cis- $L_{n}^{t}, 9\left(9^{\prime}\right)-$ cis- $L_{n}^{t}, 13\left(13^{\prime}\right)$ - cis $-L_{n}^{t}$, $\alpha-\mathrm{C}_{\mathrm{T}}^{\mathrm{AR}}, \beta-\mathrm{C}_{\mathrm{T}}^{\mathrm{AR}}$, violaxanthin $\left(\mathrm{X}_{\mathrm{n}}^{\mathrm{t}}\right)$, auro $\mathrm{X}_{\mathrm{n}}^{\mathrm{t}}$ epimers, flavo $\mathrm{X}_{\mathrm{n}}^{\mathrm{t}}$, lute $\mathrm{X}_{\mathrm{n}}^{\mathrm{t}}$, chrysanthema $\mathrm{X}_{\mathrm{n}}^{\mathrm{t}}$, $\alpha$-crypto $\mathrm{X}_{\mathrm{n}}^{\mathrm{t}}$,

\begin{tabular}{|c|c|c|}
\hline \multicolumn{2}{|c|}{ Table 1: List of minerals in $\mathbf{P}_{\text {MPN }} \mathbf{S}_{\mathbf{E d}^{*}}$} \\
\hline Components & Nutrient value & \% of RDA \\
\hline $\mathrm{Na}$ & $7 \mathrm{mg}$ & 0.5 \\
\hline $\mathrm{K}$ & $809 \mathrm{mg}$ & 17 \\
\hline $\mathrm{Ca}$ & $46 \mathrm{mg}$ & 4.5 \\
\hline $\mathrm{Cu}$ & $1.343 \mathrm{mg}$ & 159 \\
\hline $\mathrm{Fe}$ & $8.82 \mathrm{mg}$ & 110 \\
\hline $\mathrm{Mg}$ & $592 \mathrm{mg}$ & 148 \\
\hline $\mathrm{Mn}$ & $4.543 \mathrm{mg}$ & 198 \\
\hline $\mathrm{P}$ & $1.233 \mathrm{mg}$ & 176 \\
\hline $\mathrm{Se}$ & $9.4 \mu \mathrm{g}$ & 17 \\
\hline $\mathrm{Zn}$ & $7.81 \mathrm{mg}$ & 71 \\
\hline
\end{tabular}

$\beta$-crypto $X_{n}^{t}$ are also present. ${ }^{26-28}$ Acylated phenolic glycosides $\left(G^{\text {ly }}\right)$ such as cucurbitoside F, H, I, K, L, M, 23-24- dihydro $\mathrm{C}_{\mathrm{CBT}}$ lariciresinol $\left(\mathrm{L}_{\mathrm{S}}^{\mathrm{CR}}\right)$, seco-iso $\mathrm{L}_{\mathrm{S}}^{\mathrm{CR}}$, iso

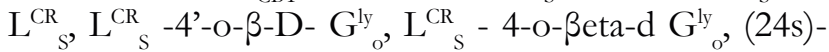
stigmata- 7,22E, 25-trien- 3-one, (24s)-stigmasta-7,22 E, 25 -trien-3beta-ol, $\mathrm{C}_{\mathrm{CBT}}$ L 2-O- $\beta$-D-glucopyranoside. ${ }^{29-31}$ Others Phytoconstituents are also exhibited in Table 3.

\section{Anti- $\mathrm{C}_{\mathrm{NCR}}$ Mechanism of C. pepo}

$\mathrm{C}_{\mathrm{NCR}}$ is the deregulation product of programmed $\mathrm{C}_{\mathrm{EL}}$ death. Numerous favorable goals for mediation is recognized by reviewing the molecular defects such as the signal transduction $\mathrm{P}_{\mathrm{tw}}$ that control $\mathrm{A}_{\mathrm{ppt}}$. In this viewpoint, $\mathrm{P}_{\mathrm{MPN}} \mathrm{S}_{\mathrm{Ed}}$ comprising of $\mathrm{C}_{\mathrm{CBT}}$ and its derivatives have developed a new emphasis for $\mathrm{C}_{\mathrm{NCR}}$ drug discovery because of its durable ability to inhibit different types of $\mathrm{C}_{\mathrm{NCR}}$. $\mathrm{C}_{\mathrm{CBT}}$ and its byproducts inhibit $\mathrm{C}_{\mathrm{NCR}}$ development by a comprehensive variety of mechanisms $\left(\mathrm{M}_{\mathrm{ehs}}\right)$, comprising of pro- $\mathrm{A}_{\mathrm{ppt}}$, installment of autophagy, $\mathrm{C}_{\mathrm{EL}}$ cycle seizure, inhibition of $\mathrm{C}_{\mathrm{NCR}}$ entrenchment and shifting. $\mathrm{C}_{\mathrm{CBT}}$ also modifies numerous intracellular $\mathrm{S}_{\mathrm{gls}} \mathrm{P}_{\mathrm{tw}}$ [Figure 3]. $\mathrm{S}_{\mathrm{gls}}$ transducers and

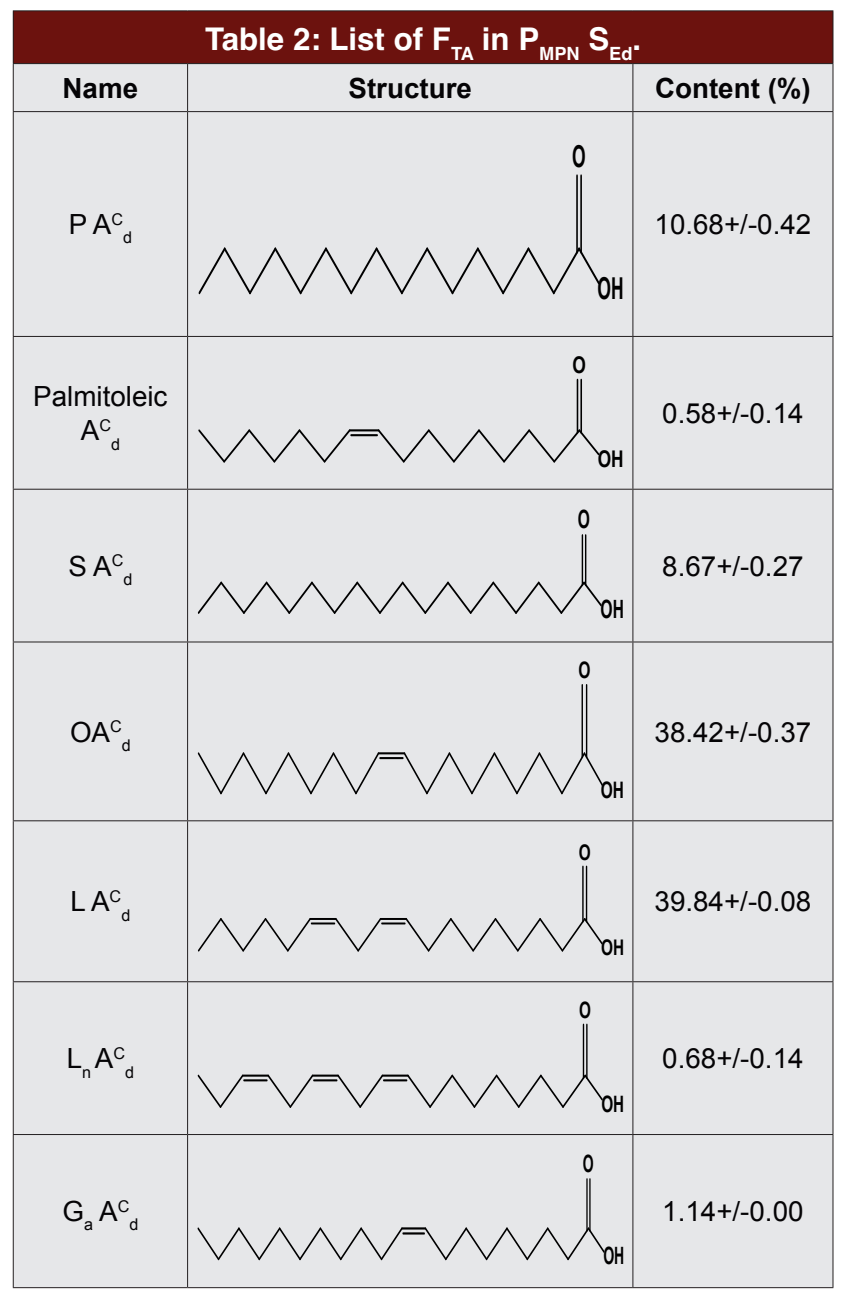




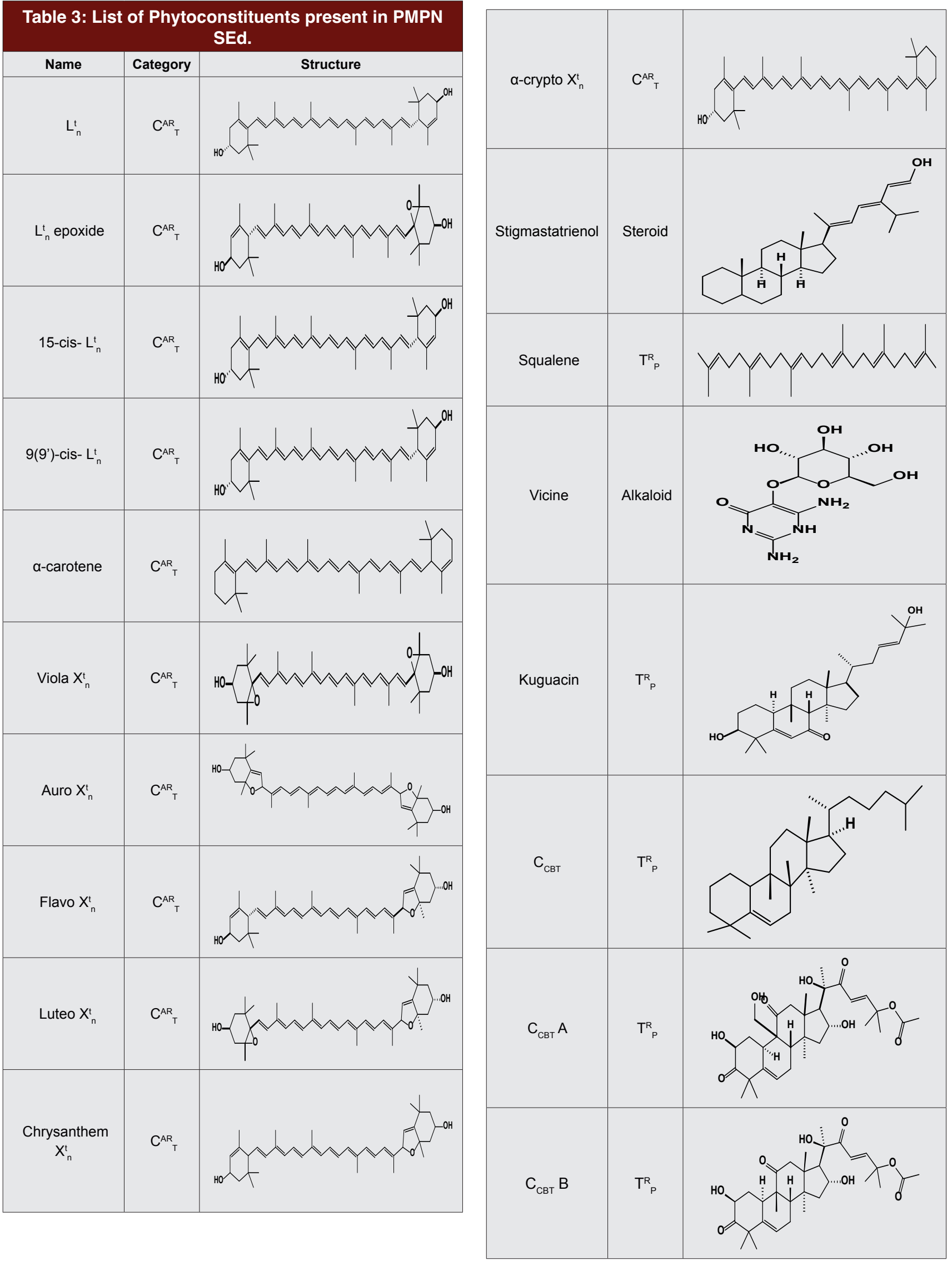




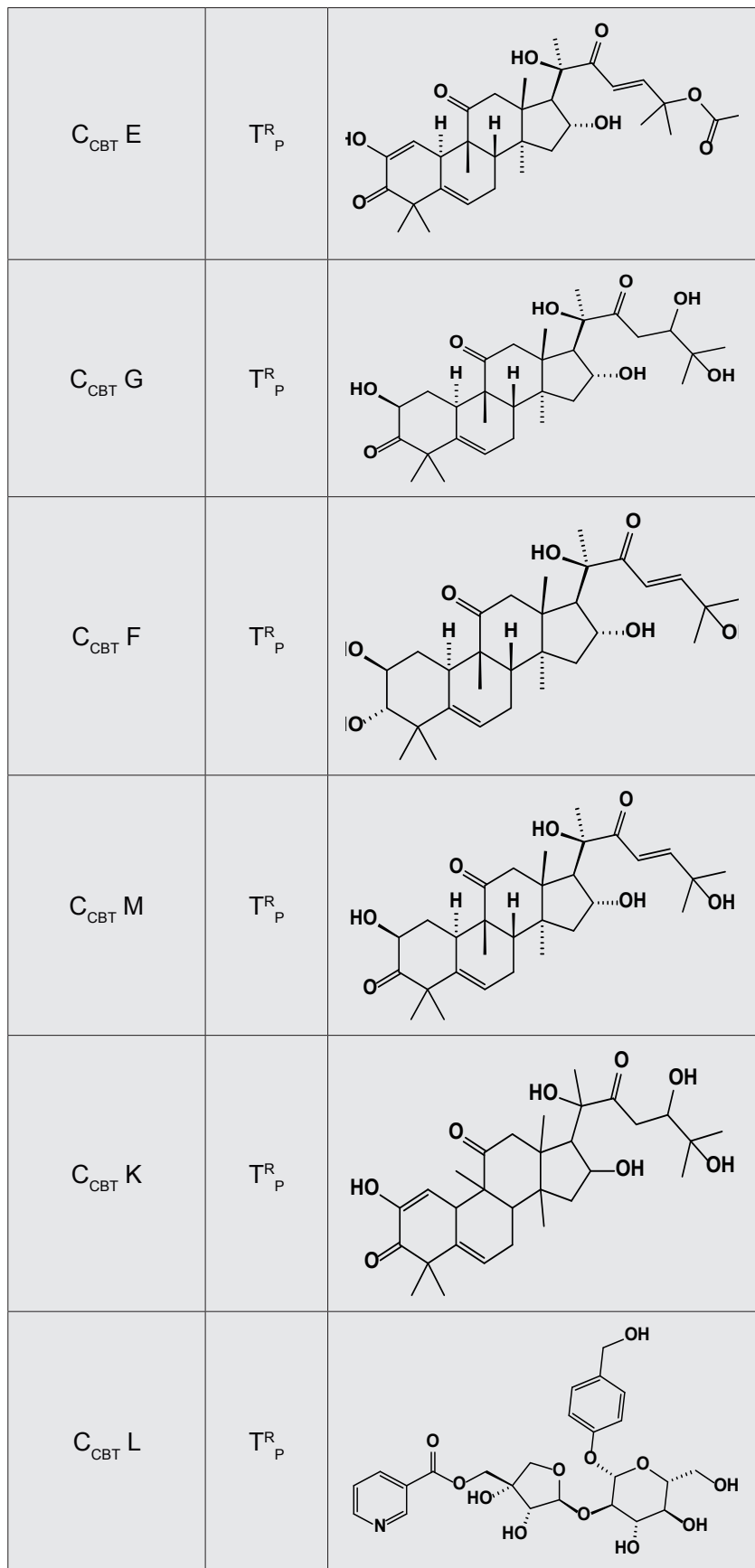

activators of transcription $\left(\mathrm{T}_{\mathrm{R}}{ }^{\mathrm{S}}\right) 3$ and Janus enzyme $\mathrm{S}_{\text {gls }}$ $\mathrm{P}_{\text {tw }}$ are the key $\mathrm{M}_{\text {ehs }}$ for $\mathrm{C}_{\mathrm{CBT}}$ to speak into necrobiosis to place forth their compelling malignant $\left(\mathrm{M}_{\mathrm{L}}^{\mathrm{AG}}\right)$ neoplasm impact. The capability of $\mathrm{C}_{\mathrm{CBT}}$ to prevail $\mathrm{C}_{\mathrm{EL}}$ cycling in the G2/M part by diversified controllers is additionally a major approach to fight different $\mathrm{C}_{\mathrm{NCR}} \cdot{ }^{32}$ STAT3 $\left(\mathrm{S}_{\mathrm{ta}}{ }^{3}\right)$ controls the exposition of genes $\left(\mathrm{G}^{\mathrm{n}}\right)$ which intercede multiplication (e.g., c-myc and cyclin D1), lowers activities of pro-apoptotic $\mathrm{G}_{\mathrm{e}}^{\mathrm{n}}$ (e.g., Bcl-xL, $\mathrm{Bcl}-2$ and surviving) and/or accelerates maturation through vascular epithelial tissue protein (VEGF). Conversely, cytokines $\left(\mathrm{C}_{\mathrm{tK}}\right)$ will inhibit the STAT-3 $\mathrm{S}_{\text {gls }}$

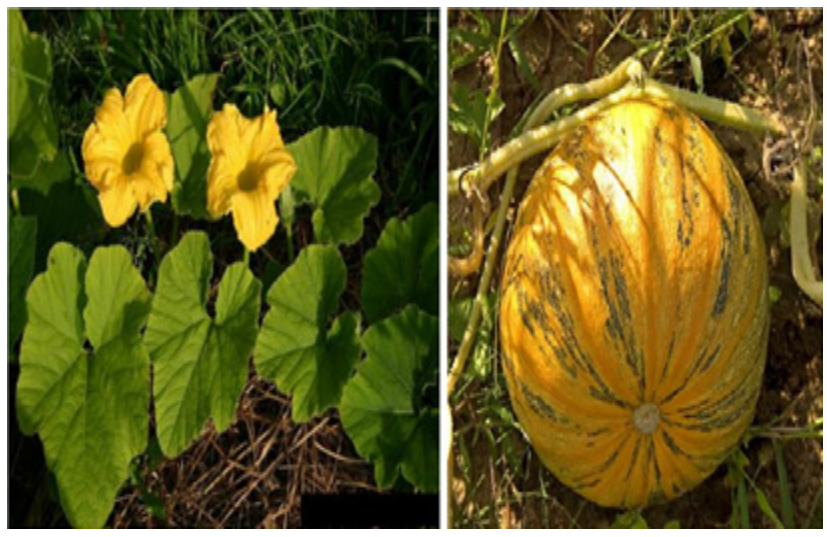

Figure 1: Pumpkin Flowers and Fruits.

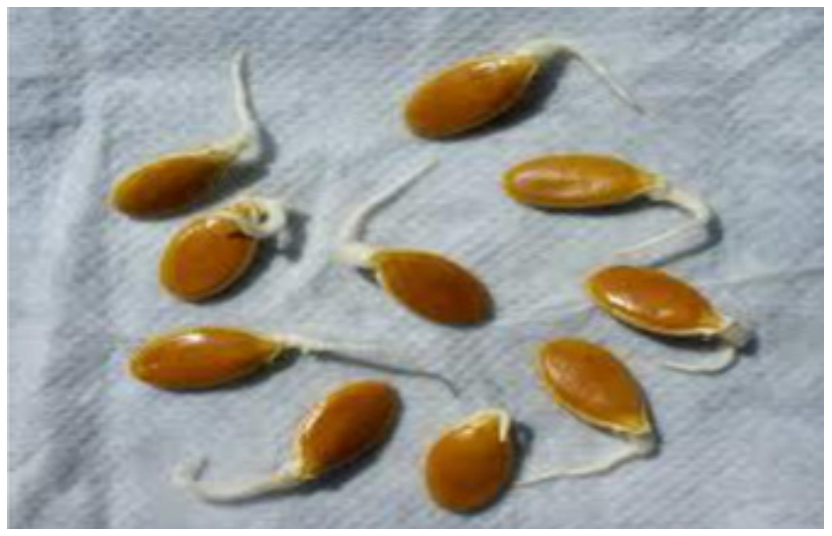

Figure 2: Germinated Pumpkin seed.
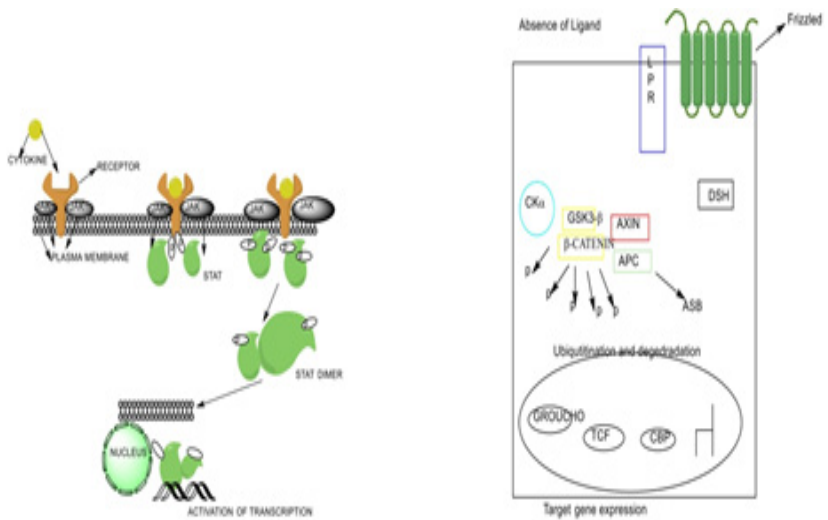

Figure 3: JAK/STAT and WNT Signaling Pathway.

$P_{t w}$ Protein empirical $G_{e}^{n}$, enacting the obliterator of $\mathrm{C}_{\mathrm{tK}}$ communication super molecule family, binding to JAK, represent the major negative regulators of the $\mathrm{JAK} / \mathrm{S}_{\mathrm{ta}}{ }^{3} \mathrm{~S}_{\mathrm{gls}} \mathrm{P}_{\mathrm{tw}}$. In recent past, it is accepted that $\mathrm{S}_{\mathrm{ta}}{ }^{3}$ may also be called up by several alternative $\mathrm{C}_{\mathrm{tK}}$, like IL-7, IL-10, IL-20, leptin, WBC colony-stimulating issue and cuticular protein. ${ }^{33}$ Admist the seven human STAT $\mathrm{G}^{\mathrm{n}}$, $\mathrm{S}_{\mathrm{ta}}{ }^{3}$, a typical oncogenic communication $\mathrm{P}_{\mathrm{tw}}$, is integrally called up in many sorts of $\mathrm{C}_{\mathrm{NCR}}$, together with eighty- 
two of glandular $\mathrm{C}_{\text {Arom }}$, seventieth of breast $\left(\mathrm{B}_{\mathrm{R}}^{\mathrm{st}}\right) \mathrm{C}_{\mathrm{NCR}}$, over eighty two of the $\mathrm{C}_{\text {Arom }}$ of the top and neck, seventy one of cavity $\mathrm{M}_{\mathrm{L}}^{\mathrm{AG}}$ neoplastic $\left(\mathrm{N}_{\mathrm{E}}^{\mathrm{pls}}\right) \mathrm{D}_{\mathrm{SEAS}}$, over five hundredth respiratory organ $\mathrm{C}_{\mathrm{NCR}}$ and five hundredth of HCC, lymphomas and myelomas. ${ }^{34}$ Uncontrolled doings of $\mathrm{S}_{\mathrm{ta}}{ }^{3}$ is unquestionable in an exceedingly form of $\mathrm{t}^{\mathrm{m}}{ }_{\mathrm{R}}$ varieties, together with $\mathrm{B}_{\mathrm{R}}^{\text {st }} \mathrm{M}_{\mathrm{L}}^{\mathrm{AG}} \mathrm{N}_{\mathrm{E}}{ }^{\text {pls }} \mathrm{D}_{\text {SEAS }}, \mathrm{P}_{\mathrm{r}}^{\text {st }} \mathrm{C}_{\mathrm{NCR}}$, melanoma, multiple myeloma and $\mathrm{C}_{\mathrm{NCR}}$ of the blood. ${ }^{35,36}$ Numerous $G^{\mathrm{n}}{ }_{e}$ mutations cause organic activation of $\mathrm{S}_{\mathrm{ta}}{ }^{3}$, as for example over-phrasing and organic triggering of cuticular protein receptor (EGFR). ${ }^{37} \mathrm{~S}_{\mathrm{ta}}{ }^{3}$ takes part to $\mathrm{t}_{\mathrm{R}}^{\mathrm{m}}$ growth by widening the $\mathrm{C}_{\mathrm{EL}}$ cycle by warding off necrobiosis and speculating onco $G^{\mathrm{n}}{ }_{\mathrm{e}}$ like $\mathrm{c}-\mathrm{Myc}$ and $\mathrm{Bcl}-\mathrm{X} . \mathrm{S}_{\mathrm{ta}}{ }^{3}$ has lately been incontestable to enhance glandular $\mathrm{C}_{\text {Arom }}$ metastasis by nurturing $\mathrm{P}_{\mathrm{r}}^{\text {st }}$ $\mathrm{C}_{\mathrm{NCR}} \mathrm{C}_{\mathrm{EL}}$ exodus. $\mathrm{C}_{\mathrm{CBT}}$ are identified as $\mathrm{A}_{\mathrm{t}}^{\mathrm{n}} \mathrm{t}_{\mathrm{R}}^{\mathrm{m}}$ agents associated with other $\mathrm{M}_{\text {ehs }}$, like conflicting with $\mathrm{S}_{\mathrm{ta}}{ }^{3} \mathrm{~S}_{\mathrm{gls}}$. They also influence the virtue of the actin cytoskeleton. As for instance, $C_{C B T} E$ wards off the propagation of glandular $\mathrm{C}_{\mathrm{Arom}} \mathrm{C}_{\mathrm{EL}}$ and disrupts the body architecture of simple protein and supplements. ${ }^{38}$ However, $\mathrm{C}_{\mathrm{CBT}} \mathrm{A}$, $\mathrm{B}, \mathrm{E}, \mathrm{I}$ impede the phosphorylation $\left(\mathrm{P}_{\mathrm{H} \mathrm{R}}^{\mathrm{S}}\right.$ ) of $\mathrm{S}_{\mathrm{ta}}{ }^{3}$ and/ or JAK2 and same way rules out $\mathrm{S}_{\mathrm{ta}}{ }^{3}$ deoxyribonucleic $\mathrm{A}_{\mathrm{d}}^{\mathrm{C}}{ }_{\mathrm{d}}$-attachment and $\mathrm{S}_{\mathrm{ta}}{ }^{3}$-mediated cistron $\mathrm{T}_{\mathrm{R}}{ }^{\mathrm{SC}}$ in $\mathrm{C}_{\text {Arom }}$ A549 line. ${ }^{39}$ Similiarly, $\mathrm{C}_{\mathrm{CBT}}$ I causes debasement of $\mathrm{P}_{\mathrm{H} \mathrm{R}}^{\mathrm{S}}$ - $\mathrm{S}_{\mathrm{ta}}{ }^{3}$ in the $\mathrm{B}_{\mathrm{R}}^{\mathrm{st}}, \mathrm{P}_{\mathrm{r}}^{\text {st }}$ and exocrine gland $\mathrm{M}_{\mathrm{L}}^{\mathrm{AG}} \mathrm{N}_{\mathrm{E}} \mathrm{pl}^{\mathrm{pls}} \mathrm{D}_{\text {SEAS }}$ $\mathrm{C}_{\mathrm{EL}}$ lines (MDA-MB-231, MDA-MB-468 and Panc-1). Amazingly $\mathrm{C}_{\mathrm{CBT}} \mathrm{B}$ and $\mathrm{E}$ are set out to persuade $\mathrm{P}_{\mathrm{H}}^{\mathrm{s}} \mathrm{R}$ of $\mathrm{S}_{\text {ta }}{ }^{3}$ in $\mathrm{C}_{\text {Arom }} \mathrm{C}_{\mathrm{EL}}$ lines (MDA-MB-231 and MCF-7)..$^{40}$ This study indicates that $\mathrm{C}_{\mathrm{CBT}}$ exerts $\mathrm{A}_{\mathrm{t}}^{\mathrm{n}}$-tumorigenic activity by selection of $\mathrm{C}_{\mathrm{EL}}$ with activated $\mathrm{S}_{\mathrm{ta}}{ }^{3}$. In SAR consideration it is found that $5 \mathrm{C}_{\mathrm{CBT}} \mathrm{A}, \mathrm{B}, \mathrm{E}, \mathrm{I}$ and $\mathrm{Q}$ obstruct the actuation of $\mathrm{S}_{\mathrm{ta}}{ }^{3}$ and produce necrobiosis. In an exceeding mouse $t^{\mathrm{m}}{ }_{\mathrm{R}}$ heterograft model, $\mathrm{C}_{\mathrm{CBT}}$ however did not suppress $\mathrm{t}_{\mathrm{R}}^{\mathrm{m}}$ growth. This indicates that JAK2 inhibition isn't adequate to ward off tmR advancement suggesting thereby the power of $\mathrm{C}_{\mathrm{CBT}}$ to impede $\mathrm{t}_{\mathrm{R}}^{\mathrm{m}}$ growth expounding its $\mathrm{A}_{\mathrm{t}}^{\mathrm{n}}-\mathrm{S}_{\mathrm{ta}}{ }^{3}$ activity. These observations more legitimize $\mathrm{S}_{\text {ta }}{ }^{3}$ as a drug exposition designing and supply proof that medical specialty assistants like $\mathrm{C}_{\mathrm{CBT}}$ may judiciously cut back the P- $\mathrm{S}_{\mathrm{ta}}{ }^{3}$ levels in human $\mathrm{C}_{\mathrm{NCR}} \mathrm{C}_{\mathrm{EL}}$. In distinction, K-Ras $\left(\mathrm{R}_{\mathrm{S}}^{\mathrm{a}}\right)$ mutations are found in thirty-five hundredths of primary large intestine $\mathrm{C}_{\mathrm{NCR}}$ besides as in entrenched $\mathrm{C}_{\text {Arom }} \mathrm{C}_{\mathrm{EL}}$ lines. Thus, the company of oncogenic $\mathrm{K}-\mathrm{R}_{\mathrm{S}}^{\mathrm{a}}$ considerably shrivels the sensitivity of $\mathrm{C}_{\mathrm{EL}}$ to dihydro $\mathrm{C}_{\mathrm{CBT}} \mathrm{B}, \mathrm{R}$ and I presumably through $\mathrm{K}-\mathrm{R}_{\mathrm{S}}^{\mathrm{a}}$ disagreement with $\mathrm{S}_{\text {ta }}{ }^{3}$ arousal. Moreover, p53 and p21 shield $\mathrm{C}_{\mathrm{EL}}$ from necrobiosis are lured by $\mathrm{C}_{\mathrm{CBT}}$ The similar studies ascertain that reactivity of human $\mathrm{C}_{\mathrm{Arom}} \mathrm{C}_{\mathrm{EL}}$ lines to those $3 \mathrm{C}_{\mathrm{CBT}}$ falls back on the vicinity of oncogenic $\mathrm{K}$ $\mathrm{R}_{\mathrm{S}}^{\mathrm{a}}$ and $\mathrm{p} 53 / \mathrm{p} 21$ standing and establish that $\mathrm{C}_{\mathrm{CBT}}$ exerts
$A^{n}-t^{m}{ }_{R}$ genic activity within the absence of activated $\mathrm{S}_{\mathrm{ta}}{ }^{3} \cdot{ }^{41}$

\section{Induction of $A_{p p t}$}

$\mathrm{C}_{\mathrm{CBT}} \mathrm{B}, \mathrm{D}, \mathrm{E}, \mathrm{I}$ and IIa influence $\mathrm{A}_{\mathrm{ppt}}$ in different classes of $\mathrm{C}_{\mathrm{NCR}} \mathrm{C}_{\mathrm{EL}}$ by arresting the $\mathrm{S}_{\mathrm{ta}}{ }^{3} \mathrm{P}_{\mathrm{tw}} \cdot \mathrm{S}_{\mathrm{ta}}{ }^{3}$ is a $\mathrm{T}_{\mathrm{R}}{ }^{\mathrm{SC}} \mathrm{F}^{\mathrm{CT}}$ that rolls $G^{n}{ }_{e}$ expression via cross-talk with another $T_{R}{ }_{R} C$ $\mathrm{F}^{\mathrm{CT}}$, such as $\beta-\left(\mathrm{B}_{\mathrm{c}}^{\mathrm{n}}\right)$, hypoxia-inducible factor-1, nuclear factor-B, c-myc, c-jun and closing off $\mathrm{S}_{\mathrm{ta}}{ }^{3}$ stimulation influenced $A_{p p t} C_{C B T} B$ has distinct structural ups and downs as symbol for $A_{p p e}$, which consists of nuclear fragmentation, chromatin contraction and embodiment of apoptotic bodies. $\mathrm{C}_{\mathrm{CBT}} \mathrm{B}$ may be significant for both inflecting the empathy of $\mathrm{C}_{\mathrm{NCR}} \mathrm{C}_{\mathrm{EL}}$ to cytotoxic lymphocyte and inspiring $\mathrm{A}^{\mathrm{n}} \mathrm{C}_{\mathrm{NCR}}$ immunity by the prohibition of the JAK2/ $\mathrm{S}_{\mathrm{ta}}{ }^{3} \mathrm{P}_{\mathrm{tw}}$ These $\mathrm{M}_{\text {ehs }}$ pinpoint that prohibition of the $\mathrm{JAK} / \mathrm{S}_{\mathrm{ta}}{ }^{3} \mathrm{P}_{\mathrm{tw}}$ with $\mathrm{C}_{\mathrm{CBT}} \mathrm{B}$ may be impressive in $\mathrm{C}_{\mathrm{NCR}}$ immunotherapy. Moreover, in human colon adeno $\mathrm{C}_{\text {Arom }}$, the $\mathrm{C}_{\mathrm{CBT}}$ B-influenced- $\mathrm{A}_{\mathrm{ppt}}$ is sustained by a reactive oxygen species system instead of that of $\mathrm{S}_{\mathrm{ta}}{ }^{3} \cdot \mathrm{C}_{\mathrm{CBT}} \mathrm{D}$ stimulates the apoptotic $\mathrm{P}_{\mathrm{tw}}$ by annihilating $\mathrm{S}_{\mathrm{ta}}^{3}$ activity in $\mathrm{B}_{\mathrm{R}}^{\text {st }} \mathrm{C}_{\mathrm{NCR}} \mathrm{C}_{\mathrm{EL}}$ and splitting fragments to procaspase-3, procaspase -9 and PARP in human endometrial as well as ovarian $\mathrm{C}_{\mathrm{NCR}} \mathrm{C}_{\mathrm{EL}}{ }^{42-45}$

\section{Induction of Autophagy}

$\mathrm{C}_{\mathrm{CBT}}$, specifically $\mathrm{C}_{\mathrm{CBT}} \mathrm{B}$ and $\mathrm{I}$, activate autophagosome development. They also initiate the gathering and changing over from light chain 3-I to LC3II in several $\mathrm{C}_{\mathrm{EL}}$ classes basically through inflation of production of mitochondrial-derived ROS and consequently activating ERK and JNK. Initiation is accomplished through the calling up of AMP-triggered protein kinase $\left(\mathrm{K}_{\mathrm{s}}^{\mathrm{N}}\right)$ / mammalian target of $\mathrm{p} 70 \mathrm{~S} 6 \mathrm{~K} \mathrm{P}_{\mathrm{tw}}$ instead of PI3K/Akt $\mathrm{P}_{\mathrm{tw}}{ }^{46}$

\section{Induction of Cell Cycle Arrest}

In human $\mathrm{C}_{\mathrm{EL}}$ cycle changeover is organized by holoenzymes comprising of reciprocally regulatory and catalytic cyclin-dependent $\mathrm{K}_{\mathrm{s}}^{\mathrm{N}} \cdot \mathrm{CDK}\left(\mathrm{c}_{\mathrm{k}}^{\mathrm{D}}\right)$ inhibitors like $\mathrm{c}_{\mathrm{k}}^{\mathrm{D}} 1$, p21Waf1 and $\mathrm{p} 27 \mathrm{KIP} 1$ perform as intrinsic controllers of $\mathrm{C}_{\mathrm{EL}}$ cycle by hooking up to $\mathrm{c}^{\mathrm{D}}{ }_{\mathrm{k}}$ complexes and lowering $\mathrm{K}^{\mathrm{N}}$ activity. ${ }^{47} \mathrm{C}_{\mathrm{CBT}}$ persuades $\mathrm{C}_{\mathrm{EL}}$ cycle blockage by reshaping different $\mathrm{S}_{\mathrm{gls}} \mathrm{P}_{\mathrm{tw}} \mathrm{C}_{\mathrm{CBT}} \mathrm{B}$ brings about $\mathrm{G} 2 / \mathrm{M} \mathrm{C}_{\mathrm{EL}}$ cycle apprehend in different $\mathrm{C}_{\mathrm{NCR}}$, such as, osteosarcoma $\mathrm{C}_{\mathrm{EL}}$, non-small $\mathrm{C}_{\mathrm{EL}}$ lung $\left(\mathrm{L}_{\mathrm{u}}^{\mathrm{G}}\right), \mathrm{B}_{\mathrm{R}}^{\text {st }}$ $\mathrm{C}_{\mathrm{NCR}}$, glioblastoma multiform, cutaneous squamous $\mathrm{C}_{\mathrm{EL}}$, laryngeal squamous and pancreatic $\mathrm{C}_{\mathrm{EL}} \mathrm{C}_{\mathrm{Arom}}{ }^{48-54}$

\section{Inhibition of $\mathbf{C}_{\mathrm{NCR}}$ Invasion and Migration}

$\mathrm{C}_{\mathrm{CBT}} \mathrm{B}$ significantly destroys $\mathrm{C}_{\mathrm{EL}}$ migration and invasion induced by impeding the $\mathrm{P}_{\mathrm{H} \mathrm{R}}^{\mathrm{S}}$ of Akt, p38 and ERK1/2 and the down-settlement of MMP-9. $\mathrm{C}_{\text {СвT }}$ E destroys 


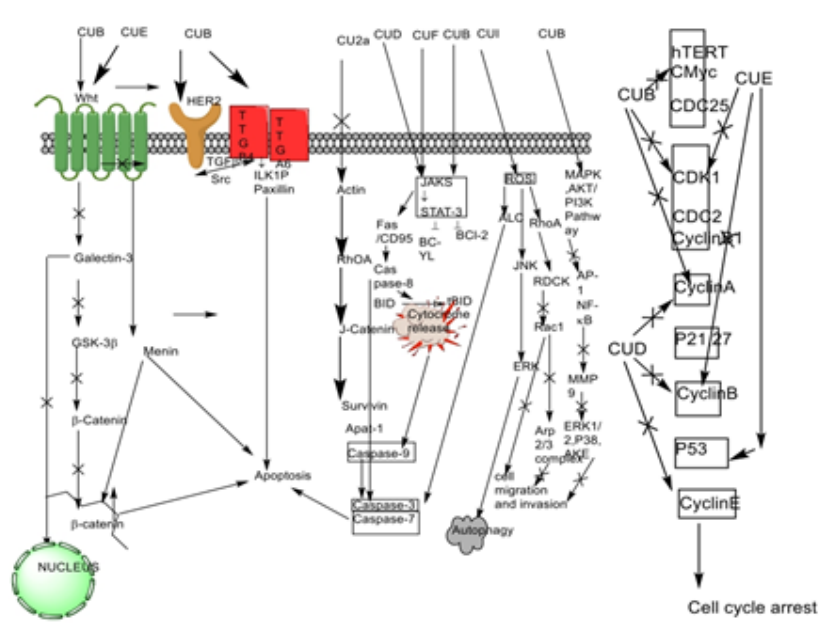

Figure 4: Mechanisms for anticancer activity of $C$. pepo. For apoptosis, Cucurbitacin B (CuB) and Cucurbitacin E (CuE) inhibit Wnt and STAT3 signaling pathways; CuB inhibits HER2 and integrin signaling pathways and elevates intracellular level of ROS; CuD inhibits STAT3 activation; Cu lla inhibits survivin. For autophagy, Cul increases intracellular level of ROS. To inhibit cell migration and invasion, $\mathrm{CuE}$ and $\mathrm{Cul}$ inhibit Rac1 activation and $\mathrm{Cu} B$ inhibits phosphorylation of ERK1/2,p38 and Akt. For cell cycle arrest, CuB, CuD, CuE down-regulate protein expression of key regulators of cell cycle.

$\mathrm{B}_{\mathrm{R}}^{\text {st }} \mathrm{C}_{\mathrm{NCR}}$ metastasis by distracting Arp/23-reliant actin polymerization and hindering the Src/FAK/Rac/JNK/ MMP $S_{\text {gls }} P_{\text {tw. }}{ }^{55-85} \mathrm{C}_{\mathrm{CBT}} \mathrm{B}$ management restrains cyclin $\mathrm{D} 1, \mathrm{c}-\mathrm{Myc}$ and $\mathrm{B}_{\mathrm{c}}^{\mathrm{n}}$ view height, alteration to the nucleus of $\mathrm{B}_{\mathrm{c}}{ }^{\mathrm{n}}$ and galectin-3. Summarized form of $\mathrm{A}^{\mathrm{n}}{ }_{\mathrm{t}}-\mathrm{C}_{\mathrm{NCR}}$ $M_{\text {ehs }}$ is shown in Figure 4.

\section{CONCLUSION}

It may be concluded that due to phytochemical, pharmacological and nutritional values, C. pepo has attained high importance throughout the world. The available research data on $\mathrm{C}_{\mathrm{CT}}$ indicate its $\mathrm{M}_{\text {edc }}$ value especially for hyperplasia, $\mathrm{P}_{\mathrm{r}}^{\text {st }} \mathrm{C}_{\mathrm{NCR}}$, urinary $\mathrm{D}_{\text {SEAS }}$, nephritis, bronchitis, hemorrhoid and anemia. The $\mathrm{M}_{\text {edc }}$ properties of $C$. pepo are due to the presence of different phytochemicals like Triterpene $\left(\mathrm{T}_{\mathrm{p}}^{\mathrm{R}}\right)$, alkaloid, cardiac $\mathrm{G}^{\text {ly }}$, etc. So, increasing $\mathrm{M}_{\text {edc }}$ value of $C$. pepo is demanding for the discovery of more potential phytochemicals which can lead to the improvement in drug formulation system. Pharmacological studies confirm the $\mathrm{A}^{\mathrm{n}}{ }_{\mathrm{t}}$ bacterial, $\mathrm{A}_{\mathrm{t}}^{\mathrm{n}}$ viral, $\mathrm{A}^{\mathrm{n}}{ }_{\mathrm{t}}$ ulcer and $\mathrm{A}_{{ }_{t}}^{\mathrm{n}}{ }^{\mathrm{m}}{ }_{\mathrm{R}}$ activities that provide scientific basis to the use of $C$. pepo based on the traditional medicines but there is no report for formulation development. Different $C_{C B T}$ compounds are also used to inhibit uncontrolled $\mathrm{C}_{\mathrm{EL}}$ division and induce $A_{p p t}$ using plentiful $C_{N C R} C_{E L}$ lines of human and $t^{m}{ }_{R}$ xenografting of leukemia, lymphoma, $\mathrm{B}_{\mathrm{R}}{ }^{\text {st }}, \mathrm{P}_{\mathrm{r}}^{\text {st }}, \mathrm{L}_{\mathrm{u}}{ }_{\mathrm{G}}^{\mathrm{G}}$, uterine cervix, liver, ${ }_{\mathrm{N}}^{\mathrm{Sk}}$, colon, laryngeal, brain and pancreatic $\mathrm{C}_{\mathrm{NCR}}$. $\mathrm{C}_{\mathrm{CBT}}$ has also the capacity to prevent $\mathrm{P}_{\mathrm{H} \mathrm{R}}^{\mathrm{S}}$ of $\mathrm{S}_{\mathrm{ta}}{ }^{3}$ and/or JAK2 and their consecutive invigoration play the sizable role in terms of mode of operation. $\mathrm{C}_{\mathrm{CBT}}$ warrant eventual inquisitions exploring their exposition in uninvestigated origins and their offshoots for bettering the $\mathrm{A}_{\mathrm{t}}^{\mathrm{n}}-\mathrm{C}_{\mathrm{NCR}}$ competence. Moreover, preclinical and clinical abstraction involving united regimen including $\mathrm{C}_{\mathrm{CBT}}$ and standard chemoimmune- and/or radio-therapies should be programmed for future strategies.

\section{ACKNOWLEDGEMENT}

To maintain scientific publishing ethics, authors are thankful to "URKUND" report of plagiarism.

\section{CONFLICT OF INTEREST}

Authors declare that there is no conflict of interest in this manuscript.

\section{ABBREVIATIONS}

$\mathbf{A}_{\mathrm{C}}{ }^{\mathrm{d}}$ : Amino acids; $\mathbf{A}_{\mathbf{t}}^{\mathrm{n}}$ : Anti; Appt: Apoptosis; $\mathbf{B}_{\mathbf{R}}{ }^{\text {st: }}$ : Breast; $\mathrm{C}_{\mathrm{NCR}}$ : Cancer; $\mathrm{C}_{\mathrm{CNG}}$ : Carcinogenesis; $\mathrm{C}_{\text {Arom }}$ : Carcinomas; $\mathrm{C}_{\mathrm{T}}^{\mathrm{AR}}$ : Carotenoids; $\mathbf{c}_{\mathrm{k}}^{\mathrm{D}}$ : $\mathrm{CDK} ; \mathbf{C}_{\mathrm{EL}}$ : Cell; $\mathrm{C}_{\mathrm{CT}}$ : Cucurbita; $\mathrm{C}_{\text {Свт: }}$ : Cucurbitacin; $\mathrm{C}_{\mathrm{tK}}$ : Cytokines; $\mathbf{D}_{\text {SEAS: }}$ : Diseases; $\mathbf{F}^{\text {CT. }}$ : Factors; $\mathbf{F}_{\text {TA }}:$ Fatty acids; $\mathbf{F}_{\mathbf{r}}^{\text {ut: }}$ Fruit; $\mathbf{G}_{\mathrm{e}}^{\mathrm{n}}$ : Genes; $\mathbf{G}^{\mathrm{ly}}$ : Glycosides; $\mathbf{K}_{\mathrm{s}}^{\mathrm{N}}$ : Kinase; $\mathbf{L}^{\mathrm{CR}}$ : Lariciresinol; $\mathbf{L ~} \mathbf{A}_{\mathrm{d}}^{\mathrm{C}}$ : Linoleic; $\mathbf{L}_{\mathrm{u}}{ }^{\mathrm{G}}$ : Lung; $\mathbf{L}_{\mathrm{n}}^{\mathrm{t}}$ : Lutein; $\mathbf{M}_{\mathbf{L}}^{\mathrm{AG}}$ : Malignant; $\mathbf{M}_{\mathrm{ehs}}$ : Mechanisms; $\mathbf{M}_{\mathrm{edc}}$ : Medicinal; $\mathbf{N}_{\mathbf{E}}{ }^{\text {pls }}$ : Neoplastic; $\mathbf{O A}_{\mathrm{d}^{\mathrm{C}}}$ : Oleic acids; $\mathbf{P} \mathbf{A}_{\mathbf{d}^{\mathrm{C}}}$ : Palmitic; $\mathbf{P}_{\text {tw }}$ : Pathway; $\mathbf{P}_{\mathrm{Lt}}$ : Plant; $\mathbf{P}_{\mathrm{r}}^{\text {st: }}$ Prostate; $\mathbf{P}_{\text {MPN }}$ : Pumpkin; $\mathbf{R}_{\mathrm{S}}{ }^{a}$ : Ras; $\mathrm{S}_{\mathrm{Ed}}$ : Seed; $\mathrm{S}_{\mathrm{gls}}$ : Signaling; ${ }_{\mathrm{N}}$ : Skin; $\mathrm{S}_{\mathrm{ta}}{ }^{3}$ : STAT3; $\mathbf{S} \mathbf{A}_{\mathbf{d}^{\mathbf{C}}}$ : Stearic acids; $\mathbf{T}_{\mathbf{R}}{ }^{\text {SC: }}$ : Transcription; $\mathbf{T}_{\mathbf{P}^{\mathrm{R}}}$ : Triterpene; $\mathbf{t}_{{ }_{\mathrm{R}}}^{\mathrm{m}}$ : Tumor; $\mathbf{X}_{\mathrm{n}}^{\mathrm{t}}$ : Xanthine.

\section{REFERENCES}

1. Bishayee A, Sethi G. Bioactive natural products in cancer prevention and therapy: Progress and promise. In Seminars in cancer biology. 2016;40:1-3. Academic Press.

2. Harlev E, Nevo E, Lansky EP, Lansky S, Bishayee A. Anticancer attributes of desert plants: A review. Anti-Cancer Drugs. 2012;23(3):255-71.

3. Adebayo OR, Farombi AG, Oyekanmi AM. Proximate, mineral and antinutrient evaluation of pumpkin pulp (Cucurbita pepo). Journal of Applied Chemistry. 2013;4(4):25-8.

4. Amin T, Naik HR, Hussain SZ, Jabeen A, Thakur M. In-vitro antioxidant and antibacterial activities of pumpkin, quince, muskmelon and bottle gourd seeds. Journal of Food Measurement and Characterization. 2018;12(1):18290.

5. Montesano D, Rocchetti G, Putnik P, Lucini L. Bioactive profile of pumpkin: An overview on terpenoids and their health-promoting properties. Current Opinion in Food Science. 2018;22:81-7.

6. Perez GRM. Review of Cucurbita pepo (pumpkin) its phytochemistry and pharmacology. Medicinal Chemistry. 2016;6(1):12-21. 
7. Yadav M, Jain S, Tomar R, Prasad GB, Yadav H. Medicinal and biological potential of pumpkin: An updated review. Nutrition Research Reviews. 2010;23(2):184-90.

8. Whitaker TW, Davis GN. Cucurbits. Botany, cultivation and utilization. Cucurbits. Botany, cultivation and utilization. 1962.

9. Lim TK. Cucurbita pepo. InEdible Medicinal and Non-Medicinal Plants. Springer, Dordrecht. 2012;281-94.

10. Halberstein RA. Botanical medicines for diuresis: Cross-cultural comparisons. In Studies in Natural Products Chemistry. Elsevier. 2012;37:1-41.

11. Akin G, Arslan FN, Elmasa SK, Yilmaz I. Cold-pressed pumpkin seed (Cucurbita pepo L.) oils from the central Anatolia region of Turkey: Characterization of phytosterols, squalene, tocols, phenolic acids, carotenoids and fatty acid bioactive compounds. Grasas y Aceites. 2018;69(1):232.

12. Farhoosh R, Gohari AA, Haddad KMH. Frying Stability of Canola Oil in the Presence of Pumpkin Seed and Olive Oils. In $8^{\text {th }}$ Euro Fed Lipid Congress. 2010.

13. Blaskovich MA, Sun J, Cantor A, Turkson J, Jove R, Sebti SM. Discovery of JSI-124 (cucurbitacin I), a selective Janus kinase/signal transducer and activator of transcription 3 signaling pathway inhibitor with potent antitumor activity against human and murine cancer cells in mice. Cancer Research. 2003;63(6):1270-9.

14. Chu KH, Xing H, inventors; Ultra Biotech Ltd, assignee. Method of inducing apoptosis in cancer treatment by using cucurbitacins. United States Patent Application US 11/954,805. 2008.

15. Cordell GA. Alice, Benzene and Coffee: The ABCs of Ecopharmacognosy. Natural product communications. 2015;10(12):1934578X1501001243.

16. Ardabili AG, Farhoosh R, Khodaparast MH. Frying stability of canola oil in presence of pumpkin seed and olive oils. European Journal of Lipid Science and Technology. 2010;112(8):871-7.

17. Glew RH, Glew RS, Chuang LT, Huang YS, Millson M, Constans D, et al. Amino acid, mineral and fatty acid content of pumpkin seeds (Cucurbita spp) and Cyperus esculentus nuts in the Republic of Niger. Plant Foods for Human Nutrition. 2006;61(2):49-54.

18. Hao-bo W, Xiu-wu G, Jin-hua G, Qun-ce H, Zeng-liang Y. Genetic transformation of watermelon with pumpkin DNA by low energy ion beammediated introduction. Plasma Science and Technology. 2002;4(6):1591.

19. Kaushik U, Aeri V, Mir SR. Cucurbitacins-an insight into medicinal leads from nature. Pharmacognosy Reviews. 2015;9(17):12.

20. Suebsakwong P, Wang J, Khetkam P, Weerapreeyakul N, Wu J, Du Y, et al. A Bioreductive Prodrug of Cucurbitacin B Significantly Inhibits Tumor Growth in the 4T1 Xenograft Mice Model. ACS Medicinal Chemistry Letters. 2019;10(10):1400-6.

21. Rios JL, Andújar I, Escandell JM, Giner RM, Recio MC. Cucurbitacins as inducers of cell death and a rich source of potential anticancer compounds. Current Pharmaceutical Design. 2012;18(12):1663-76.

22. Lange T. Molecular biology of gibberellin synthesis. Planta. 1998;204(4):40919.

23. Lessire M, Gallo V, Prato M, Akide-Ndunge O, Mandili G, Marget P, et al. Effects of faba beans with different concentrations of vicine and convicine on egg production, egg quality and red blood cells in laying hens. Animal. 2017;11(8):1270-8.

24. Li Y, Wang R, Ma E, Deng Y, Wang X, Xiao J, et al. The induction of G2/M cell-cycle arrest and apoptosis by cucurbitacin $E$ is associated with increased phosphorylation of elF2 $\alpha$ in leukemia cells. Anti-cancer Drugs. 2010;21(4):389-400.

25. Matus Z, Molnár P, Szabó LG. Main carotenoids in pressed seeds (Cucurbitae semen) of oil pumpkin (Cucurbita pepo convar. pepo var. styriaca). Acta Pharmaceutica Hungarica. 1993;63(5):247-56.

26. Meineri G, Longato E, Peiretti PG. Effects of diets containing linseed oil or lard and supplemented with pumpkin seeds on oxidative status, blood serum metabolites, growth performance and meat quality of naked neck chickens. Canadian Journal of Animal Science. 2018;98(4):607-18.

27. Montesano D, Blasi F, Simonetti MS, Santini A, Cossignani L. Chemical and nutritional characterization of seed oil from Cucurbita maxima L.(var. Berrettina) pumpkin. Foods. 2018;7(3):30.

28. Montesano D, Rocchetti G, Putnik P, Lucini L. Bioactive profile of pumpkin: an overview on terpenoids and their health-promoting properties. Current Opinion in Food Science. 2018;22:81-7.
29. Nishisho I, Nakamura Y, Miyoshi Y, Miki Y, Ando H, Horii A, Koyama K, Utsunomiya $\mathrm{J}$, et al. Mutations of chromosome $5 \mathrm{q} 21$ genes in FAP and colorectal cancer patients. Science. 1991;253(5020):665-9.

30. Nkosi CZ, Opoku AR, Terblanche SE. Antioxidative effects of pumpkin seed (Cucurbita pepo) protein isolate in CCl4-Induced liver injury in low-protein fed rats. Phytotherapy Research: An International Journal Devoted to Pharmacological and Toxicological Evaluation of Natural Product Derivatives. 2006;20(11):935-40.

31. Chen JC, Chiu MH, Nie RL, Cordell GA, Qiu SX. Cucurbitacins and cucurbitane glycosides: Structures and biological activities. Natural Product Reports. 2005;22(3):386-99.

32. Duncan KL, Duncan MD, Alley MC, Sausville EA. Cucurbitacin E-induced disruption of the actin and vimentin cytoskeleton in prostate carcinoma cells. Biochemical Pharmacology. 1996;52(10):1553-60.

33. Liu T, Zhang M, Zhang H, Sun C, Yang X, Deng $Y$, et al. Combined antitumor activity of cucurbitacin $\mathrm{B}$ and docetaxel in laryngeal cancer. European Journal of Pharmacology. 2008;587(1-3):78-84.

34. Haritunians T, Gueller S, Zhang L, Badr R, Yin D, Xing H, et al. Cucurbitacin $B$ induces differentiation, cell cycle arrest and actin cytoskeletal alterations in myeloid leukemia cells. Leukemia Research. 2008;32(9):1366-73.

35. Ren S, Ouyang DY, Saltis M, Xu LH, Zha QB, Cai JY, et al. Anti-proliferative effect of 23, 24-dihydrocucurbitacin $F$ on human prostate cancer cells through induction of actin aggregation and cofilin-actin rod formation. Cancer Chemotherapy and Pharmacology. 2012;70(3):415-24.

36. Ríos JL, Recio MC. Natural products as modulators of apoptosis and their role in inflammation. In Studies in Natural Products Chemistry. Elsevier. 2006;33:141-92.

37. Garg S, Kaul SC, Wadhwa R. Anti-Stress and glial differentiation effects of a novel combination of cucurbitacin B and withanone (CucWi-N): Experimental evidence. Annals of Neurosciences. 2018;25:201-9.

38. Asgary S, Moshtaghian SJ, Setorki M, Kazemi S, Rafieian-Kopaei M, Adelnia $A$, et al. Hypoglycaemic and hypolipidemic effects of pumpkin (Cucurbita pepo L.) on alloxan-induced diabetic rats. African Journal of Pharmacy and Pharmacology. 2011;5(23):2620-6.

39. Shi X, Franko B, Frantz C, Amin HM, Lai R. JSI-124 (cucurbitacin I) inhibits Janus kinase-3/signal transducer and activator of transcription-3 signalling, downregulates nucleophosmin-anaplastic lymphoma kinase (ALK) and induces apoptosis in ALK-positive anaplastic large cell lymphoma cells. British Journal of Haematology. 2006;135(1):26-32.

40. Shynu M, Gupta KP, Saini M. Antineoplastic potential of medicinal plants. Recent Patents on Biotechnology. 2011;5(2):85-94.

41. Smith BD. The initial domestication of Cucurbita pepo in the Americas 10,000 years ago. Science. 1997;276(5314):932-4.

42. Song $\mathrm{Y}, \mathrm{Ni} \mathrm{Y}, \mathrm{Hu} \mathrm{X}, \mathrm{Li} \mathrm{Q}$. Effect of phosphorylation on antioxidant activities of pumpkin (Cucurbita pepo, Lady godiva) polysaccharide. International Journal of Biological Macromolecules. 2015;81:41-8.

43. Su Y, Li G, Zhang X, Gu J, Zhang C, Tian Z, Zhang J. JSI-124 inhibits glioblastoma multiforme cell proliferation through $\mathrm{G} 2 / \mathrm{M}$ cell cycle arrest and apoptosis augmentation. Cancer Biology and Therapy. 2008;7(8):1243-9.

44. Sun C, Zhang M, Shan X, Zhou X, Yang J, Wang Y, et al. Inhibitory effect of cucurbitacin E on pancreatic cancer cells growth via STAT3 signaling. Journal of Cancer Research and Clinical Oncology. 2010;136(4):603-10.

45. Sun J, Blaskovich MA, Jove R, Livingston SK, Coppola D, Sebti SM. Cucurbitacin Q: a selective STAT3 activation inhibitor with potent antitumor activity. Oncogene. 2005;24(20):3236-45.

46. Thoennissen NH, Iwanski GB, Doan NB, Okamoto R, Lin P, Abbassi S, et al. Cucurbitacin $B$ induces apoptosis by inhibition of the JAK/STAT pathway and potentiates antiproliferative effects of gemcitabine on pancreatic cancer cells. Cancer Research. 2009 Jul 15;69(14):5876-84.

47. Türkmen Ö, Özcan MM, Seymen M, Paksoy M, Uslu N, Fidan S. Physicochemical properties and fatty acid compositions of some edible pumpkin seed genotypes and oils. Journal of Agroalimentary Processes and Technologies. 2017;23(4):229-35.

48. Kester MSV, Out-Luiting JJ, Peter A, Willemze R, Tensen CP, Vermeer MH. Cucurbitacin I inhibits Stat3 and induces apoptosis in Sezary cells. Journal of Investigative Dermatology. 2008;128(7):1691-5. 
49. Wang HX, Ng TB. Natural products with hypoglycemic, hypotensive, hypocholesterolemic, antiatherosclerotic and antithrombotic activities. Life Sciences. 1999;65(25):2663-77.

50. Wang XL, Liu J, Chen ZH, Gao F, Liu JX, Wang XL. Preliminary study on pharmacologically effect of Curcurbita pepo cv Dayanggua. J Tradit Chin Vet Med. 2001;20:6-9.

51. Klungsaeng S, Kukongviriyapan V, Prawan A, Kongpetch S, Senggunprai L. Cucurbitacin B induces mitochondrial-mediated apoptosis pathway in cholangiocarcinoma cells via suppressing focal adhesion kinase signaling. Naunyn-Schmiedeberg's Archives of Pharmacology. 2019;392(3):271-8.

52. Cheng AC, Hsu YC, Tsai CC. The effects of cucurbitacin E on GADD45 $\beta$ trigger G2/M arrest and JNK-independent pathway in brain cancer cells. Journal of Cellular and Molecular Medicine. 2019;23(5):3512-9.

53. Menchinskaya E, Gorpenchenko T, Silchenko A, Avilov S, Aminin D. Modulation of doxorubicin intracellular accumulation and anticancer activity by triterpene glycoside cucumarioside A2-2. Marine Drugs. 2019;17(11):597.

54. Yadav M, Jain S, Tomar R, Prasad GB, Yadav H. Medicinal and biological potential of pumpkin: an updated review. Nutrition Research Reviews. 2010;23(2):184-90.

55. Adebayo OR, Farombi AG, Oyekanmi AM. Proximate, mineral and antinutrient evaluation of pumpkin pulp (Cucurbita pepo). Journal of Applied Chemistry. 2013;4(4):25-8.

56. Wu Y, Zhou R, Wang Z, Wang B, Yang Y, Ju X, et al. The effect of refining process on the physicochemical properties and micronutrients of rapeseed oils. PloS One. 2019;14(3):e0212879.

57. Alfawaz MA. Chemical composition and oil characteristics of pumpkin (Cucurbita maxima) seed kernels. Food Science and Agriculture. 2004;2(1):518.

58. Andrews P, Collins WJ, Stern WR. The effect of withholding water during flowering on seed production in Trifolium subterraneum L. Australian Journal of Agricultural Research. 1977;28(2):301-7.

59. Blaskovich MA, Sun J, Cantor A, Turkson J, Jove R, Sebti SM. Discovery of JSI-124 (cucurbitacin I), a selective Janus kinase/signal transducer and activator of transcription 3 signaling pathway inhibitor with potent antitumor activity against human and murine cancer cells in mice. Cancer Research. 2003;63(6):1270-9.

60. Copeland LO, McDonald MB. Seed formation and development. In Principles of Seed Science and Technology Springer, Boston, MA. ;

61. Cordell GA. Alice, Benzene and Coffee: The ABCs of Ecopharmacognosy. Natural product communications. 2015;10(12):1934578X1501001243.

62. Hunyadi A, Gergely A, Simon A, Tóth G, Veress G, Báthori M. Preparativescale chromatography of ecdysteroids of Serratula wolffii Andrae. Journal of Chromatographic Science. 2007;45(2):76-86.

63. El-Boghdady NA. Protective effect of ellagic acid and pumpkin seed oil against methotrexate-induced small intestine damage in rats. Indian Journal of Biochemistry and Biophysics. 2011;48(6):380-7.

64. Gamlath CB, Gunatilaka AL, Alvi KA, Balasubramaniam S. Cucurbitacins of Colocynthis vulgaris. Phytochemistry. 1988 Jan 1;27(10):3225-9.

65. Glew RH, Glew RS, Chuang LT, Huang YS, Millson M, Constans D, Vanderjagt DJ. Amino acid, mineral and fatty acid content of pumpkin seeds (Cucurbita spp) and Cyperus esculentus nuts in the Republic of Niger. Plant foods for human nutrition. 2006 Jun 1;61(2):49-54.

66. Naz I, Ramchandani S, Khan MR, Yang MH, Ahn KS. Anticancer Potential of Raddeanin A, a Natural Triterpenoid Isolated from Anemone raddeana Regel. Molecules. 2020; 25(5):1-20.
67. Gohari aa, farhoosh $\mathrm{r}$, haddad $\mathrm{km}$. Chemical composition and physicochemical properties of pumpkin seeds (Cucurbita pepo Subsp. pepo Var. Styriaka) grown in Iran. Journal of Agricultural Science and Technology. 2011.

68. Griffiths DJ, EW B. Problems of breeding for seed production in grasses. 1980.

69. Halliwell B. The role of oxygen radicals in human disease, with particular reference to the vascular system. Pathophysiology of Haemostasis and Thrombosis. 1993;23(Suppl. 1):118-26.

70. Hao-bo W, Xiu-wu G, Jin-hua G, Qun-ce H, Zeng-liang Y. Genetic transformation of watermelon with pumpkin DNA by low energy ion beammediated introduction. Plasma Science and Technology. 2002;4(6):1591.

71. Herr JM. Embryology and taxonomy. In Embryology of angiosperms. Springer, Berlin, Heidelberg. 1984;647-96.

72. Hojima Y, Pierce JV, Pisano JJ. Pumpkin seed inhibitor of human factor XIla (activated Hageman factor) and bovine trypsin. Biochemistry. 1982;21(16):3741-6.

73. Gry J. Cucurbitacins in plant food. Nordic Council of Ministers. 2006.

74. Kinghorn AD, Pan L, Fletcher JN, Chai $H$. The relevance of higher plants in lead compound discovery programs. Journal of Natural Products. 2011;74(6):1539-55.

75. Balliano G, Caputo O, Viola F, DelPrino L, Cattel L. The transformation of 10a-cucurbita-5, 24-dien-3 $\beta$-ol into cucurbitacin $C$ by seedlings of Cucumis sativus. Phytochemistry. 1983;22(4):909-13.

76. Witkowski A, Woynarowska B, Konopa J. Inhibition of the biosynthesis of deoxyribonucleic acid, ribonucleic acid and protein in HeLa S3 cells by cucurbitacins, glucocorticoid-like cytotoxic triterpenes. Biochemical pPharmacology. 1984 Apr 1;33(7):995-1004.

77. Itkin M, Davidovich-Rikanati R, Cohen S, Portnoy V, Doron-Faigenboim $\mathrm{A}$, Oren $\mathrm{E}$, et al. The biosynthetic pathway of the nonsugar, high-intensity sweetener mogroside $V$ from Siraitia grosvenorii. Proceedings of the National Academy of Sciences. 2016;113(47):E7619-28.

78. Panossian A, Gabrielian E, Wagner H. On the mechanism of action of plant adaptogens with particular reference to cucurbitacin $\mathrm{R}$ diglucoside. Phytomedicine. 1999;6(3):147-55.

79. Zehnder G, Kloepper J, Tuzun S, Yao C, Wei G, Chambliss O, et al. Insect feeding on cucumber mediated by rhizobacteria-induced plant resistance. Entomologia Experimentalis et Applicata. 1997;83(1):81-5.

80. Stuppner H, Wagner H. New cucurbitacin glycosides from Picrorhiza kurrooa. Planta Medica. 1989;55(06):559-63.

81. Viterbo A, Staples RC, Yagen B, Mayer AM. Selective mode of action of cucurbitacin in the inhibition of laccase formation in Botrytis cinerea. Phytochemistry. 1994;35(5):1137-42.

82. Laurent P, Braekman JC, Daloze D, Pasteels J. Biosynthesis of defensive compounds from beetles and ants. European Journal of Organic Chemistry. 2003;2003(15):2733-43.

83. Lodeiro S, Segura MJ, Stahl M, Schulz-Gasch T, Matsuda SP. Oxidosqualene cyclase second-sphere residues profoundly influence the product profile. Chem Bio Chem. 2004 Nov 5;5(11):1581-5.

84. Saker M, El Gengaihi S, Kamel A, Farid M. Influence of differentiation state, salt stress and methyl jasmonate on in vitro production of cucurbitacins from tissue cultures of Ecballium elaterium and Cucumis prophetarum endemic to Egypt. Medicinal and Aromatic Plant Science and Biotechnology. 2010;4(1):28-32.

85. Luckner M. Biosynthesis of isoprenoids. InSecondary Metabolism in Microorganisms, Plants and Animals. Springer, Berlin, Heidelberg. 1984;199256. 
PICTORIAL ABSTRACT
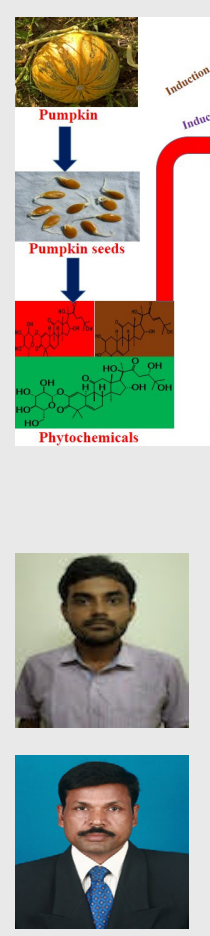

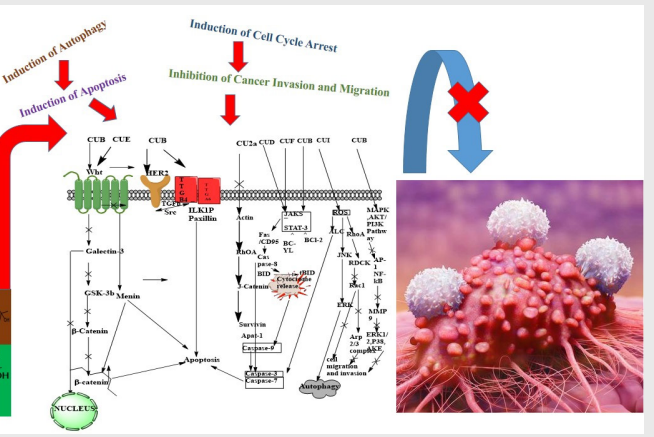

- Pumpkin seed contains cucurbitacin and its derivatives

- They are anti-proliferative agents

- These are blocked by JAK/STAT signaling pathway

- Blocking by JAK/STAT signaling pathway may involve several mechanisms such as induction of autophagy, induction of cell cycle arrest, induction of apoptosis, and inhibition of cancer Invasion and migration.

\section{About Authors}

Souvik Mukherjee, born in Memari, West Bengal and M. Pharm from Central University, Punjab has published research articles and book chapters in different reputed journals and books respectively.

Dr. Dilipkumar Pal is now working in the post of Associate Professor, in Department of Pharmacy, Guru Ghasidash Vishwavidyalaya (A Central University), Bilaspur, C.G., India. He received his master and Ph.D degree from Jadavpur University, Kolkata and performed post-doctoral research as "Endeavour research fellow" in University of Sydney, Australia. He has published 171 full research papers in peer-reviewed national and international scientific journals and contributed 117 abstracts in different national and international conferences. He has written 2 books and 63 book chapters and edited 06 books published by reputed international publishers. His research publications have acquired a highly remarkable cited record in Scopus and Google Scholar (H-Index: 41; i-10-index 99, citation 5445 till date). Dr. Pal in his 21 years research-oriented teaching profession received 13 prestigious national and international professional awards also. He is the reviewer and Editorial Board member of 27 and 29 scientific journals, respectively and recently, Dr. Pal has been included in world's top $2 \%$ Indian Scientist (sub: Pharmacy and Pharmacology).

Cite this article: Mukherjee S, Pal D. Cucurbita pepo and Cucurbitacin in the Management of Anti-proliferation by JAK/STAT Pathway. Indian J of Pharmaceutical Education and Research. 2021;55(1):1-10. 